\title{
Pharmacognostical and Physico-chemical Standardization of Euphorbia neriifolia Leaves
}

\author{
Prashant Y. Mali* and Shital S. Panchal
}

Prashant Y. Mali* and Shital S. Panchal

Department of Pharmacology, Institute of Pharmacy, Nirma University, Ahmedabad-382481, Gujarat, INDIA

\section{Correspondence}

Prashant Y. Mali, Department of Pharmacology, Institute of Pharmacy, Nirma University, Ahmedabad-382481, Gujarat, INDIA

Tel.: +91-0755-2896237

Mobile: +91-9822284089

Tele fax: +91-0755-2896660

E-mail: pymali2008@rediffmail.com

History

- Submission Date: 31-05-2017;

- Review completed: 18-06-2017;

- Accepted Date: 28-06-2017

DOI : 10.5530/pj.2017.5.110

Article Available online

http://www.phcogj.com/v9/i5

Copyright

(C) 2017 Phcog.Net. This is an openaccess article distributed under the terms of the Creative Commons Attribution 4.0 International license.

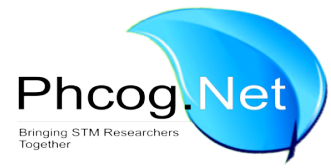

\begin{abstract}
Objective: To investigate pharmacognostical and physico-chemical standardization of Euphorbia neriifolia leaves. Materials and Methods: Fresh and dried leaves with powder samples of E. neriifolia were examined macroscopically and microscopically. As per Ayurvedic Pharmacopeia of India and World Health Organization guidelines on quality control methods for medicinal plants materials suggested parameters were determined for standardization of $E$. neriifolia leaves. Physico-chemical, primary phytochemical, fluorescence and quantitative screenings along with primary HPTLC fingerprinting assessment were performed. Results: Macroscopic examination demonstrated that fresh leaf of $E$. neriifolia has dark green in colour, herbaceous odour with characteristic taste. Dried leafs are grey brownish in colour, characteristic odour with broken crumpled and papery fracture. Microscopy of leaf showed the single layered thick rectangular or tubular adaxial epidermal cells. Mesophyll tissue was differentiated into two or three layered adaxial zones of radially elongated palisade cells and wider abaxial spongy mesophyll cells revealed the differentiated dorsiventral lamina. Mid-rib composed of epidermis, collenchymas and spongy parenchyma cells. Physico-chemical parameters like, foreign matter was found to be $0.46 \%$. Total ash, acid insoluble ash and water soluble ash was found $6.33 \%, 1.23 \%$ and $6 \%$ respectively. Loss on drying was found to be $4.69 \%$. Swelling and foaming index was found $11.7 \mathrm{ml}$ and $333 \mathrm{ml}$ respectively. Quantitative screening suggested that the leaf powder has indicated alkaloid and saponin estimation as $0.26 \%$ and $3.67 \%$ respectively. The HPTLC fingerprinting of EN6 extract fraction was showed the Rf values at 254 $\mathrm{nm}$ with their respective UV-visible spectrum wavelengths scanned in between $200-400 \mathrm{~nm}$. They are $0.01(265 \mathrm{~nm}), 0.05(369 \mathrm{~nm}), 0.09(263 \mathrm{~nm}, 264 \mathrm{~nm}), 0.18(400 \mathrm{~nm}), 0.20(279 \mathrm{~nm})$, $0.31(400 \mathrm{~nm}), 0.44(378 \mathrm{~nm}), 0.45(382 \mathrm{~nm}), 0.54(377 \mathrm{~nm}), 0.55(383 \mathrm{~nm}), 0.62(400 \mathrm{~nm})$, etc. at different concentrations of sample application. The HPTLC plate was also scanned at $366 \mathrm{~nm}$ and $540 \mathrm{~nm}$. Conclusion: The present investigation is an additional standardization research in support with previous reports and will be helpful for qualitative and quantitative standardization of herbal formulations containing E. neriifolia. Further investigations are going on this extract fraction in reference to identification, quantification and validation of HPTLC methods using various standard marker compounds along with exploration of its pharmacological activities.

Key words: Euphorbia neriifolia, Pharmacognostical, Physico-chemical, Macroscopic, HPTLC.
\end{abstract}

\section{INTRODUCTION}

Euphorbia neriifolia Linn. Sp. Pl. (451.1753) belonging to the family Euphorbiaceae which consisting about 05 sub-families, 49 tribes, 317 genera, 800 species and one of the most important families of flowering plants of immense importance. ${ }^{1,2}$ Investigations has shown that some Euphorbiaceae has really potent therapeutic plants and their extracts have been patented as contemporary drugs. ${ }^{3,4}$ About half dozen species of Euphorbia genus are under the name of snuk and its synonyms. The latex of E. nerrifolia is an active ingredient of many Ayurvedic formulations like Abhaya lavana, Avittoladi bhasma, Citrakadi taila, Jatyadi varti, Snuhidugdhadi varti, Snuhi ghrta, Jalodarari ras, etc. E. neriifolia has been traditionally indicated in Vatavyadhi, Gulma, Udara, Sula, Sotha, Arsas, Kusta and Medoroga., E. neriifolia have to possess anaesthetic, ${ }^{7}$ analgesic, ${ }^{8,9}$ anti-anxiety / anti-convulsant / anti-psychotic, ${ }^{10}$ anti-arthritis, ${ }^{11}$ anti-carcinogenic / renal carcinogenesis / hepatocarcinogenesis, ${ }^{12-15}$ antidiabetic, ${ }^{16}$ anti-inflammatory, ${ }^{8,9,17,18}$ antioxidant, ${ }^{19,20}$ cytotoxicity, ${ }^{21,22}$ death-receptor expression enhancing activity, ${ }^{23}$ immunomodulatory, ${ }^{24,25}$ etc. properties. It is also reported to have neriifolin-S, ${ }^{26}$ neriifolin, ${ }^{27}$ neriifoliene, ${ }^{28}$ euphol, ${ }^{29}$ neriifolione and cycloartenol, ${ }^{30}$ nerifoliol, ${ }^{31}$ lectin, ${ }^{32}$ euphonerins A-G and 3-O-acetyl-8-O-tigloylingol, ${ }^{33}$ taraxerol, ${ }^{34}$ quercetin and rutin, ${ }^{35}$ and antiquorin, ${ }^{36}$ etc. phyto-compounds. India has a glorious tradition of usage of therapeutic preparations from natural herbs which have protectingandhealing propertieswithnegligiblesideeffects. ${ }^{37}$ Due to emerging interest $80 \%$ of world's population is

Cite this article : Mali PY and Panchal SS. Pharmacognostical and Physico-chemical Standardization of Euphorbia neriifolia Leaves. Pharmacog J. 2017;9(5):696-705. 
adopting traditional medicine. Government of India has initiated several attempts to explore ethanopharmacology and traditional uses of plant for evaluation of their therapeutic potential as well as help to generate data to put these botanicals in international market of public healthcare domain. ${ }^{38,39}$ A noticeably small amount of profitable phytochemical entities have entered on facts based therapeutics but hard works are still required to recognize bioactive molecules in herbal drugs. ${ }^{40}$ The present investigation provides outline of up-to-date information on pharmacognostical and physico-chemical standardization of E. neriifolia leaves.

\section{MATERIALS AND METHODS}

\section{Instruments and chemicals}

Leica photographic microscope (Leica Microsystems, Mumbai, DM-3000), U. V. chamber (Dolphin, Mumbai), Afcoset digital balance (Afcoset Balances, Mumbai, E-R-180A), analytical grade toluene, ethyl acetate, n-butanol, formic acid (98-100\%), acetone (Merck, Mumbai), chloroform, methanol, petroleum ether $\left(40-60^{\circ} \mathrm{C}\right)($ Sd Fine-Chem Ltd, Mumbai), etc. were used for the study.

\section{Authentification of E. neriifolia plant and its leaves}

Fresh, well grown E. neriifolia plant and its leaves were collected from local region of Bhopal, Madhya Pradesh, India in August-September month of 2012 and was authenticated by taxonomist, Dr. Vijay V. Bhadane, Department of Botany, Pratap College, Amalner-425401, Maharashtra, India. Voucher specimen (No. PCA/Bot-P1637) was deposited in the same. The photograph and herbarium of E. neriifolia as shown in (Figure 1)

\section{Macroscopic evaluation}

Macroscopic evaluation of fresh and dried E. neriifolia leaves were studied as per the method of Brain and Turner. ${ }^{41}$ The colour, odour, taste, condition, fracture, texture, size and shape parameters were considered for the evaluation.

\section{Microscopic evaluation}

Microscopic evaluation of fresh leaf was performed according to the procedure mentioned in the Ayurvedic Pharmacopoeia of India. ${ }^{6}$ The vascular bundle, stomata types, calcium oxalates, xylem, mesophyll and epidermal cells, trichomes, starch grains, etc. were studied. The dried powder of leaf was cleared with sodium hydroxide and mounted in glycerin medium after staining. The various staining reagents such as toluidine blue, safranin, fast green and iodine were used to study calcium oxalates crystals, starch grains, stomata, trichomes, epidermal cells, parenchyma, xylem parenchyma and lignified xylem fibers. The photographs of different magnifications were taken by Leica photographic microscope.

\section{Extraction and fractionation of E. neriifolia leaves}

Freshly collected E. neriifolia leaves were dried in shade. Course powder of dried leaves $(300 \mathrm{gm})$ was extracted successively using petroleum ether, toluene, chloroform (Non-polar), ethyl acetate, $n$-butanol and distilled water (Polar) solvents by maceration process of extraction for the period of seven days for solvent with occasional stirring. The macerate mixtures were filtered each two times with muslin cloth separately and thereafter extract fractions obtained were concentrated, dried and designated as EN1 (Petroleum ether), EN2 (Toluene), EN3 (Chloroform), EN4 (Ethyl acetate), EN5 (n-butanol) and EN6 (Aqueous). The percentage yields and consistencies of extract fractions were recorded.

\section{Physico-chemical analysis}

The percentage of foreign matter, ${ }^{42}$ total ash, acid insoluble ash, water soluble ash, ${ }^{6}$ loss on drying, ${ }^{43}$ swelling ${ }^{6}$ and foaming index ${ }^{42}$ were examined.

\section{Primary phytochemical screening}

Primary phytochemical screening of extract fractions of E. neriifolia leaves were performed to identify the presence of class of phytoconstituents like, alkaloids, amino acids, carbohydrates, flavonoids, glycosides, proteins, saponin, steroids, tannins and phenols. ${ }^{43,44}$

\section{Fluorescence analysis}

Dried powder of E. neriifolia leaves was studied for fluorescence study as such and besides after treating independently with water, $1 \mathrm{~N}$ of $\mathrm{HCl}$, $\mathrm{HNO}_{3}, \mathrm{H}_{2} \mathrm{SO}_{4}, \mathrm{NaOH}, \mathrm{KMnO}_{4}, \mathrm{KOH}$, alcoholic $\mathrm{NaOH}$ and $\mathrm{KOH}$ and ammonia using normal and ultra-violet light $(254 \mathrm{~nm})$. Colour effect of petroleum ether, toluene, chloroform, ethyl acetate, $n$-butanol and distilled water extract fractions were also observed using normal and ultra-violet light $(254 \mathrm{~nm}){ }^{45,46}$

\section{Quantitative assessment of phytoconstituents Alkaloid determination}

Alkaloid content was studied with reference to procedure mentioned by Harbone. ${ }^{47}$

\section{Saponin determination}

Saponin content was determined with reference to procedure mentioned by Obdoni and Ochuko. ${ }^{48}$

\section{Primary HPTLC fingerprinting analysis}

Based on the percentage yield and presence of phyto-constitutents in the different extract fractions, EN6 extract fraction was selective for studied by HPTLC technique for normal phase separation of components.

\section{Preparation of solution of EN6 extract fraction}

An accurately weighted $500 \mathrm{mg}$ of EN6 extract fraction and dissolved into a $5 \mathrm{ml}$ of methanol in volumetric flask respectively. It was then sonicated for $20 \mathrm{~min}$. The solution was kept a side for $30 \mathrm{~min}$ to settle down the aliquots. The aliquots of stock solution of EN6 extract fraction was transferred to $10 \mathrm{ml}$ volumetric flask and volume of was adjusted with methanol to get the final concentration $100 \mu \mathrm{g} / \mu \mathrm{l}$ of extract fraction. Further this solution was used for identification of extracted phytocompounds.

\section{Mobile phase used for primary HPTLC studies}

Toluene: Chloroform: Ethanol (4:4:2)

\section{Chromatography and HPTLC fingerprinting analysis}

A chromatographic study was performed on prewashed and preactivated $20.0 \times 10.0 \mathrm{~cm}$ aluminum Lichrosphere HPTLC plates pre-coated with silica gel $60 \mathrm{~F}_{254}$ of $0.2 \mathrm{~mm}$ thickness layer (Merck KGaA, Darmstadt, Germany). Spots of extract fraction EN6 was applied at 2, 4, 6, 8, 10 and $15 \mu \mathrm{l}$ at application position $8.00 \mathrm{~mm}$ with band length $8.00 \mathrm{~mm}$ by a CAMAG Linomat-V automatic TLC sample spotter (Camag Muttenz, Switzerland) equipped with a $100 \mu \mathrm{l}$ syringe (Hamilton) under a continuous drying stream of nitrogen gas at a constant application speed of $150 \mathrm{nl} / \mathrm{s}$. The linear ascending development with the above mobile phase in a $20.0 \times 10.0 \mathrm{~cm}$ twin trough glass chamber (CAMAG) previously saturated with mobile phase for $15 \mathrm{~min}$ at room temperature $\left(25 \pm 2{ }^{\circ} \mathrm{C}\right)$ and relative humidity $40 \%$. The development distance was $80.00 \mathrm{~mm}$ (development time $20 \mathrm{~min}$ with filter paper) and $20 \mathrm{ml}$ mobile phase was used. After development, the plate was dried with a stream of hot air and densitometric scanning was performed at $254 \mathrm{~nm}$ in absorption-reflectance mode and $366 \mathrm{~nm}$ in absorption-fluorescence mode by using a CAMAG TLC scanner 3 and CAMAG visualizer with automatic digital camera linked to win-CATS software (Version 1.4.6). 
The slit dimension of scanner was set at $6.00 \times 0.45 \mathrm{~mm}$ (Micro) with $100 \mu \mathrm{m} /$ step data resolution and $20 \mathrm{~mm} / \mathrm{s}$ scanning speed. Latter, the plate was dipped in anisaldehyde sulfuric acid derivatising reagent and plate was dried with a stream of hot air, scanned at $540 \mathrm{~nm}$ in absorptionreflectance mode with the same software system. The volume of sample applied, color of the resolved band, peak number, $\mathrm{R}_{\mathrm{f}}$ value, peak height and peak area were noted. The UV-visible spectra's were also scanned at $254 \mathrm{~nm}$ under $\mathrm{D}_{2}$ lamp with $200-400 \mathrm{~nm}$ start and end wavelengths.

\section{RESULTS}

\section{Macroscopic evaluation of E. neriifolia leaves}

The plant is herbaceous. The fresh leaves are dark green in colour with herbaceous odour, characteristics taste, rough fracture, leathery texture with size approximately 2-7 cm wide and $8-20 \mathrm{~cm}$ long. The dried leaves are grey brownish in colour with characteristic odour, tasteless, broken crumpled and papery fracture, thin and papery texture with size approximately 1.5 to $6 \mathrm{~cm}$ wide and $15-20 \mathrm{~cm}$ long. Both fresh and dried leaves are cuneate shape, base is acute and apex is sub-acute. Margins are entire even, smooth throughout with pointed and acute tip. Venation is pinnate, anastomosing near the margin. Veinlets are prominent at lower surface. Lamina is entire and flat with carks. The macroscopic photographs of E. neriifolia leaves are shown in (Figure 2).

\section{Microscopic evaluation}

T. S. of E. neriifolia leaf showed the single layered thick rectangular or tubular adaxial epidermal cells. Single to double layered abaxial epidermis with circular to rectangular epidermal cells. Mesophyll tissue was differentiated into two or three layered adaxial zones of radially elongated palisade cells and wider abaxial spongy mesophyll cells revealed the differentiated dorsiventral lamina. The spongy mesophyll had wide air chambers and partition filaments formed by lobed and interconnected 6-9 layered spongy parenchyma cells. Midrib region slightly rose on the adaxial side whereas broadly semi-circular on the adaxial side. Mid-rib composed of epidermis, collenchymas and spongy parenchyma cells. In certain regions of epidermis, five celled uncreated trichomes with blunted tip and glandular trichomes with bi-celled head were embedded. Vascular bundles are prominent towards the ventral side and covered with endodermis. The vascular bundles consist of lignified xylem and non-lignified phloem. Mesophyll cells were called idioblasts. Spongy parenchyma showed the presence of starch granules. The spongy mesophyll had wide air-chambers. E. neriifolia leaf surface showed the anomocytic type of stomata that were covered with guard cells surrounded by 2-3 subsidiary cells followed by polygonal epidermal layers. Adaxial surface contains more stomata in comparison to abaxial surface of leaf. Leaf surface also indicated presence of glandular as well as unicellular blunted trichomes. The microscopic photographs of E. neriifolia leaves are shown in (Figure 3).

The microscopic examination of powder of E. neriifolia leaves has indicated the presence of numerous idioblastic, rosette, square, prismatic and acicular shaped calcium oxalate crystals and starch grains both simple and compound, well arranged annular vessels, anomocytic stomata, unicerrate multicellular trichome, epidermal cells, spongy parenchyma, xylem parenchyma, starch grains, lignified xylem fibres and oxalate crystals. Microscopic photographs of powder of E. neriifolia leaves are shown in (Figure 4).

\section{Extraction and fractionation}

The scheme for extraction and fractionation of E. neriifolia leaves are shown in (Figure 5). The percentage yields and consistencies of all the extract fractions are shown in (Table 1).
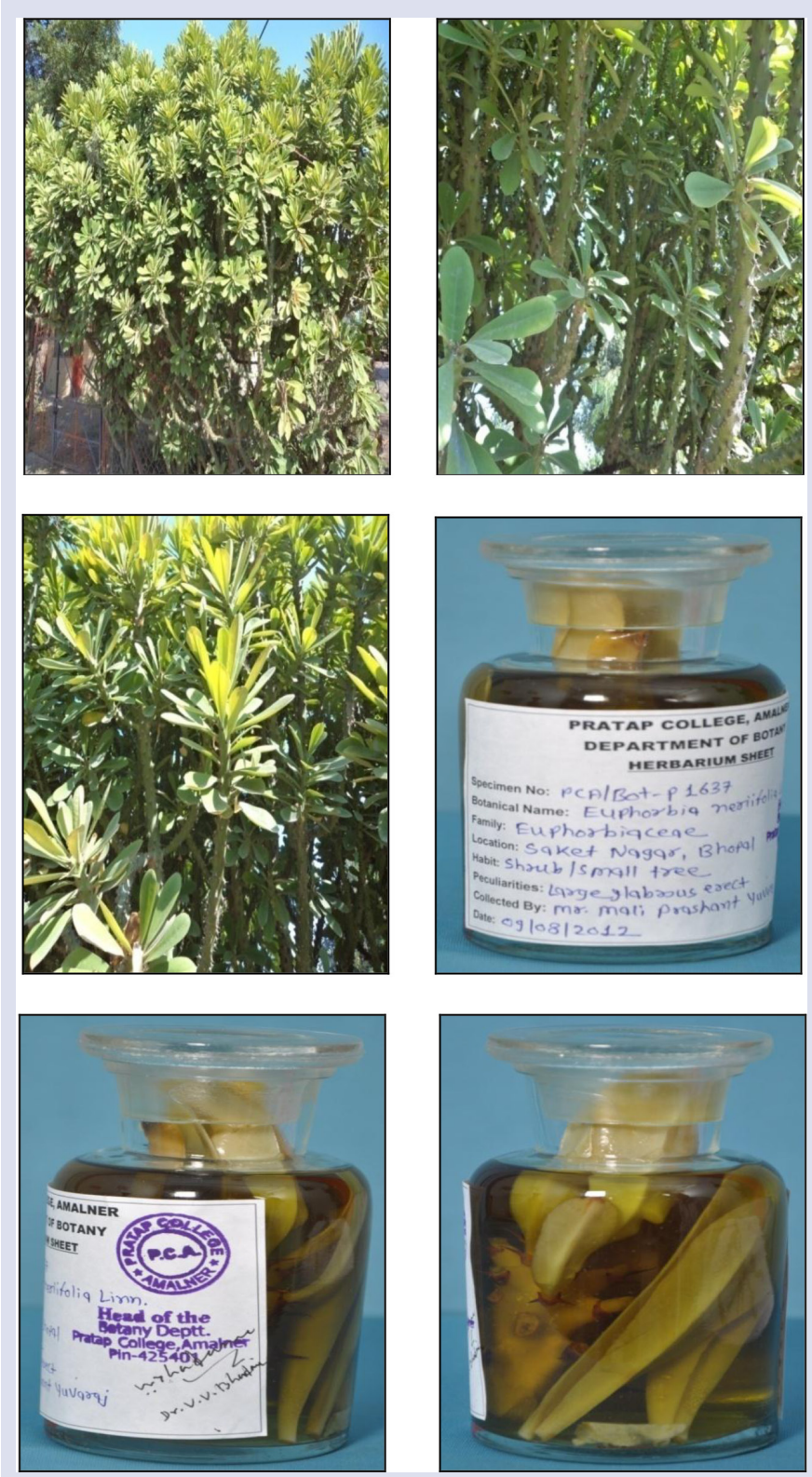

Figure 1: Photograph and herbarium of E. neriifolia Linn. (Source: Local region of Bhopal, Madhya Pradesh, India; Aug. 2012)

\section{Physico-chemical analysis}

The foreign matter was found $0.46 \%$. Total ash, acid insoluble ash and water soluble ash was found $6.33 \%, 1.23 \%$ and $6 \%$ respectively. The moisture content or loss on drying was found to be $4.69 \%$. Swelling and foaming index was found $11.7 \mathrm{ml}$ and $333 \mathrm{ml}$ respectively.

\section{Primary phytochemical screening}

The results for primary phytochemical screening of various extract fractions of E. neriifolia leaves are shown in (Table 2).

\section{Fluorescence analysis of extract fractions and powder of E. neriifolia leaves}

The results of fluorescence analysis of extract fractions of leaves as well as powder of E. neriifolia are shown in (Table 3) and (Table 4) respectively. 

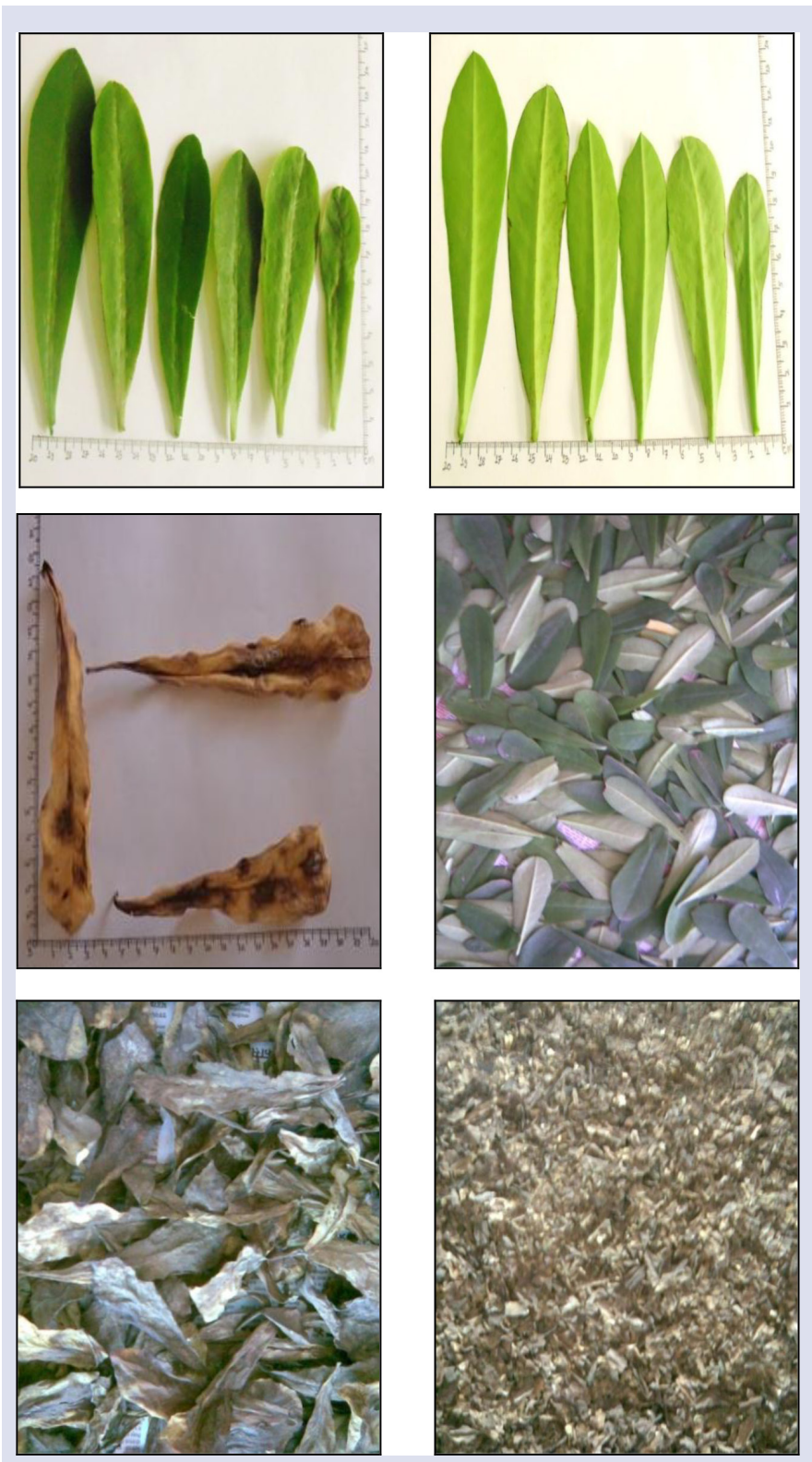

Figure 2: Macroscopic photographs of E. neriifolia leaves

\section{Quantitative assessment of phytoconstituents}

Quantitative assessment of phytoconstituents in leaf powder indicated alkaloid and saponin estimation as $0.26 \%$ and $3.67 \%$ respectively.

\section{Primary HPTLC fingerprinting analysis}

The HPTLC fingerprinting of EN6 extract fraction was showed the $R_{f}$ values at $254 \mathrm{~nm}$ with their respective UV-visible spectrum wavelengths scanned in between $200-400 \mathrm{~nm}$. They are $0.01(265 \mathrm{~nm}), 0.05(369 \mathrm{~nm})$, $0.09(263 \mathrm{~nm}, 264 \mathrm{~nm}), 0.18(400 \mathrm{~nm}), 0.20(279 \mathrm{~nm}), 0.31(400 \mathrm{~nm})$, $0.44(378 \mathrm{~nm}), 0.45(382 \mathrm{~nm}), 0.54(377 \mathrm{~nm}), 0.55(383 \mathrm{~nm}), 0.62$ $(400 \mathrm{~nm}), 0.63(400 \mathrm{~nm})$ and $0.71(397 \mathrm{~nm})$ at different concentrations of sample application. The HPTLC plate was also scanned at $366 \mathrm{~nm}$ and it was showed the different peaks with respective their $R_{f}$ values $0.05,0.12,0.19,0.27,0.32,0.34,0.33,0.41,0.44,0.45,0.54,0.55,0.70$ and 0.77 . At $540 \mathrm{~nm}$, the peaks having $\mathrm{R}_{\mathrm{f}}$ values like, $0.01,0.08,0.09,0.14$,
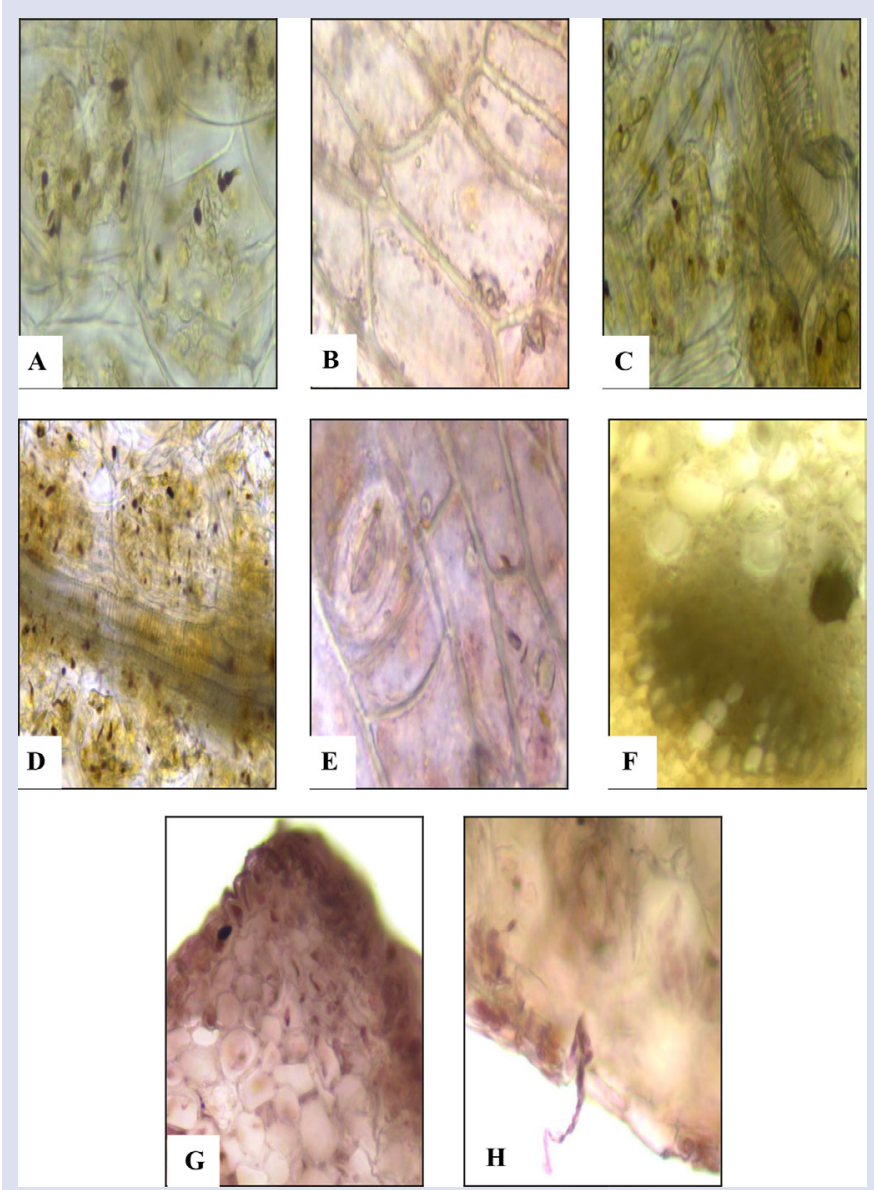

Figure 3: Microscopic photographs of $E$. neriifolia leaves. A: Idioblastic calcium oxalate crystals with simple starch granules; B: Rectagular or tubular adaxial epidermal cells; C: Mesophyll cells and annular thickening; D: Annular xylem tracheids; E: Anisocytic stomata; F: Vascular bundle; $\mathrm{G}$ : Lower surface of leaf; $\mathrm{H}$ : Trichome

$0.16,0.17,0.18,0.19,0.24,0.31,0.38,0.48,0.57,0.63,0.64,0.72$ and 0.74 were found. The scanned HPTLC white normal plate, at 254 and $366 \mathrm{~nm}$ are shown in (Figure 6) and the volume of sample applied, color of the resolved band, peak number, $\mathrm{R}_{\mathrm{f}}$ value, peak height and peak area at $254 \mathrm{~nm}$ (Table-5), $366 \mathrm{~nm}$ and $540 \mathrm{~nm}$ (Table-6).

\section{DISCUSSION AND CONCLUSION}

In spite of the accessibility of hyphenated critical techniques, identification and assessment of plant drugs by pharmacognostical and physicochemical consideration is still more reliable, precise and economical. According to WHO, macroscopic and microscopic evaluation of plant is the first step towards establishing its identity and purity. It must be performed prior to any other tests to be carried out. ${ }^{43}$ In line with above statement, we have performed the macroscopic and microscopic studies of fresh and dried leaf along with the powder of E. neriifolia. The results of macroscopic studies will be helpful for identifying it from the substitutes or adulterants. Microscopic evaluation of drug helps to categorize the ordered cellular organization of drug substance by their known histological features like epidermal cells, mesophyll cells, vascular bundles, stomata, trichomes, starch grains, etc. The use of a variety of reagents or stains helps to differentiate cellular structure depending on 

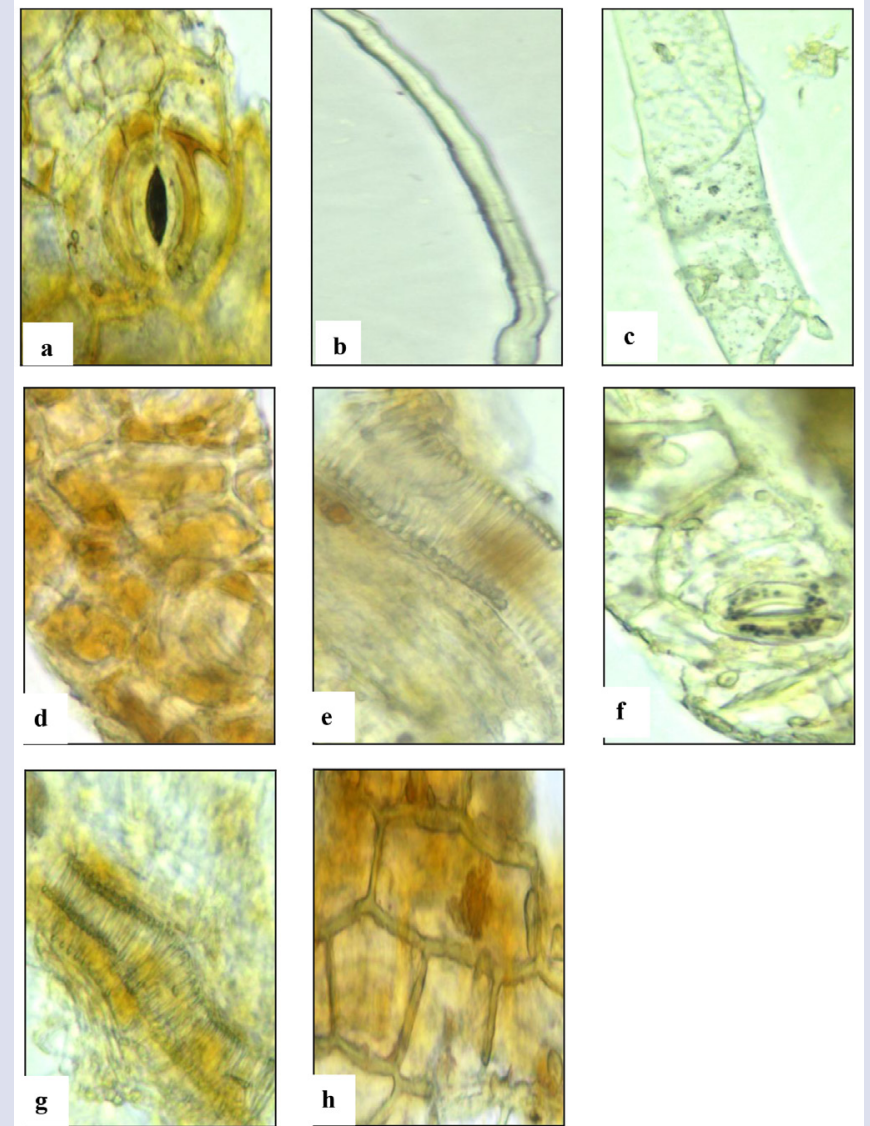

Figure 4: Microscopic photographs of powder of E. neriifolia leaves. a: Anisocytic stomata; b: Trichome; c: Starch grains; d: Lignified xylem fibre; e: Annular xylem tracheids; f: Acicular calcium oxalate in a parenchyma cells; g: Annular vessels; h: Epidermal cells

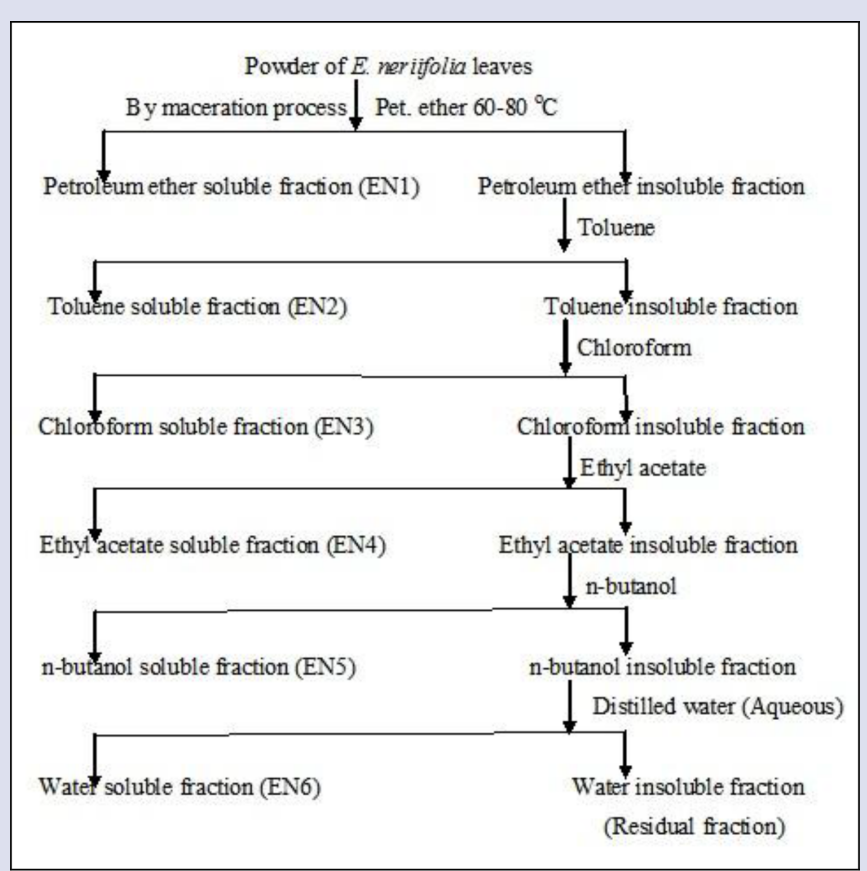

Figure 5: Extraction and fractionation scheme of E. neriifolia leaves

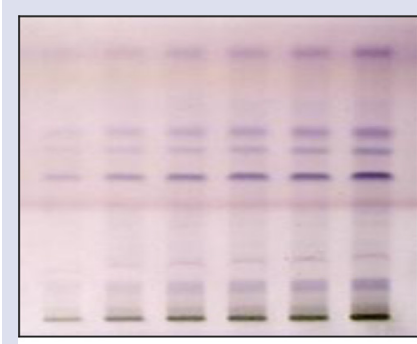

A

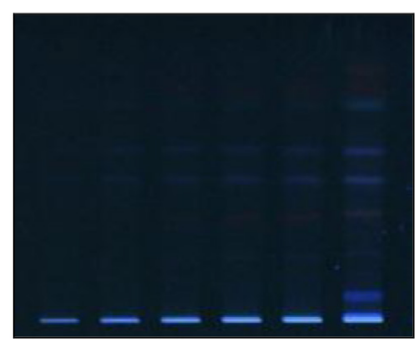

C

Figure 6: Scanned HPTLC developed plates. A: Scanned HPTLC normal white plate; B: Scanned HPTLC plate at 254nm; C: Scanned HPTLC plate at $366 \mathrm{~nm}$

their chemical character. The results suggest that powder of E. neriifolia leaves have higher aqueous extractive value followed by petroleum ether, ethyl acetate, toluene, chloroform and n-butanol. The physico-chemical parameters help in judging the purity and quality of the drug. Foreign matter was present in trace amount due to first hand procurement of plant material from non-polluted location. Ash values are useful to identify the occurrence of any siliceous infectivity and water soluble salts. They are the chief quantitative standards values and useful in shaping accuracy as well as purity of drugs. ${ }^{48}$ The results of total ash, acid insoluble ash and water soluble ash were $6.33 \%, 1.23 \%$ and $6 \%$, , respectively. Low level of total ashes is indication of little amount of carbonates, phosphates and silica in the selected plant leaves. There is a chance of presence of nonphysiological substances in the crude drugs so total ash value is not always reliable. Therefore, the authentication of acid insoluble ash was also studied. It showed ash in leaves. Loss on drying was found to be $4.69 \%$ which signify the significant amount of mucilage in leaves. Percent active chemical constituent is usually expressed on air-dried basis in crude drugs. Moisture content of drug was studied for making the solutions of exact strength. It should be minimizing for preventing the decay of crude drug because of microbial infectivity or chemical alteration. Swelling and foaming index was found in the range of $11.7 \mathrm{ml}$ and 333 due to presence of mucilage in the leaves. Results of primary phytochemical study showed that the presence of a variety of phytocompounds in the leaves which are known to have a choice of therapeutic value for curing disease ailments. EN6, the aqueous extract fraction has shown the presence of amino acids, alkaloids, flavonoids, carbohydrates, proteins, glycosides, saponin, tannins, steroids and phenols. Previous research reports suggested that saponins, flavonoids, tannins, alkaloids and phenols have anti-inflammatory activities whereas flavonoids, glycosides, alkaloids and tannins have hypoglycemic effects. ${ }^{49,50}$ Results of fluorescence analysis of extracts of E. neriifolia leaves showed its characteristic fluorescent colours in tested inorganic and organic chemicals. The fluorescent phenomenon of drug powder determines the purity and quality of plant material. Fluorescence features exhibited by many chemical constituents which indicate fluorescence at visible in day light. U.V 
Table 1: Percentage yields and consistencies of extracts of $E$. neriifolia leaves

\begin{tabular}{ccccccc}
\hline \multirow{2}{*}{ Parameters } & \multicolumn{5}{c}{ Extracts } \\
\cline { 2 - 6 } & Pet. ether & Toluene & Chloroform & Ethyl acetate & n-butanol & Aqueous \\
\hline \% yields (Codes, w/w) & $7.6 \%(\mathrm{EN} 1)$ & $1.19 \%(\mathrm{EN} 2)$ & $0.56 \%(\mathrm{EN} 3)$ & $2.36 \%(\mathrm{EN} 4)$ & $0.26 \%(\mathrm{EN} 5)$ & $8.5 \%(\mathrm{EN} 6)$ \\
Consistencies & Crystals & Crystals & Viscous & Viscous & Viscous & Viscous \\
\hline
\end{tabular}

Table 2: Preliminary phytochemical studies of extracts of E. neriifolia leaves

\begin{tabular}{|c|c|c|c|c|c|c|}
\hline Tests & EN1 & EN2 & EN3 & EN4 & EN5 & EN6 \\
\hline \multicolumn{7}{|l|}{ Alkaloids } \\
\hline Dragendorff's test & - & + & + & - & + & + \\
\hline Wagner's test & + & + & - & + & - & + \\
\hline \multicolumn{7}{|l|}{ Amino acids } \\
\hline Ninhydrin test & - & - & - & - & + & + \\
\hline Test for cysteine & - & - & - & + & - & + \\
\hline \multicolumn{7}{|l|}{ Carbohydrates } \\
\hline Molisch's test & + & + & - & - & + & + \\
\hline Fehling's test & - & - & + & - & - & + \\
\hline Iodine test & - & - & - & + & - & - \\
\hline \multicolumn{7}{|l|}{ Flavonoids } \\
\hline Test with conc. $\mathrm{H}_{2} \mathrm{SO}_{4} \& \mathrm{Mg}(\mathrm{A})$ & + & + & - & + & - & + \\
\hline Test with aq. $\mathrm{NaOH}(\mathrm{B})$ & - & - & - & - & + & + \\
\hline Test with conc. $\mathrm{H}_{2} \mathrm{SO}_{4}(\mathrm{C})$ & - & - & + & - & + & - \\
\hline Shinoda test & + & + & - & + & - & + \\
\hline Pew’s test & - & + & - & - & - & + \\
\hline \multicolumn{7}{|l|}{ Glycosides } \\
\hline Legal's test & + & - & + & - & - & + \\
\hline Killer-Killani test & - & + & - & + & + & + \\
\hline \multicolumn{7}{|l|}{ Proteins } \\
\hline Biuret test & - & - & + & + & - & + \\
\hline Million's test & - & - & - & - & + & + \\
\hline Precipitation test & - & - & - & + & - & + \\
\hline \multicolumn{7}{|l|}{ Saponin } \\
\hline Foam test & + & + & + & - & + & + \\
\hline Molisch's test & + & + & - & + & - & + \\
\hline \multicolumn{7}{|l|}{ Steroids } \\
\hline Salkowski test & + & + & - & - & + & + \\
\hline Libermann-Burchard test & - & - & + & - & - & + \\
\hline \multicolumn{7}{|l|}{ Tannins \& phenols } \\
\hline Phenol test & + & + & + & - & - & + \\
\hline Test with $5 \%$ of $\mathrm{FeCl}_{3}(\mathrm{~A})$ & - & - & - & + & + & + \\
\hline Test with lead acetate (B) & + & + & + & + & - & - \\
\hline Test with acetic acid (C) & - & - & - & - & + & + \\
\hline Test with dilute iodine (D) & - & - & + & + & - & + \\
\hline Test with dilute $\mathrm{KMnO}_{4}(\mathrm{E})$ & - & - & - & - & - & + \\
\hline
\end{tabular}

Where, EN1- Petroleum ether; EN2-Toluene; EN3-Chloroform; EN4-Ethyl acetate; EN5-n-butanol; EN6-Aqueous; "+" = Presence of constituents; "-" = Absence of constituents

Table 3: Colour reactions of extracts of E. neriifolia leaves in normal and U.V. light

\begin{tabular}{ccccccc}
\hline \multirow{2}{*}{$\begin{array}{c}\text { Observation } \\
\text { Under }\end{array}$} & EN1 & EN2 & EN3 & EN4 & EN5 & EN6 \\
\cline { 2 - 6 } Normal / Day Light & Gold & Olive & Peru & Yellowish gray & Burly wood & Dark slate gray \\
U.V. Light $(254 \mathrm{~nm})$ & Yellow & Golden rod & Olive drab & Olive & Yellow green & Yellowish dark slate gray \\
\hline
\end{tabular}

Where, EN1- Petroleum ether; EN2-Toluene; EN3-Chloroform; EN4-Ethyl acetate; EN5-n-butanol; EN6-Aqueous 
Table 4: Fluorescence analysis of powder of E. neriifolia leaves in normal \& U.V. light

\begin{tabular}{ccc}
\hline & \multicolumn{2}{c}{ Observation } \\
\cline { 2 - 3 } Powder + Solvents & Normal / Day Light & U.V. Light (254 nm) \\
\hline Dry powder & Grayish brown & Grayish brown \\
Powder + water & Light yellow & Yellowish green \\
Powder $+\mathrm{HCl}$ & Faint yellow & Pale green \\
Powder $+\mathrm{HNO}_{3}$ & Golden & Pale golden \\
Powder $+\mathrm{H}_{2} \mathrm{SO}_{4}$ & Pale golden & Pale golden \\
Powder $+\mathrm{NaOH}$ & Yellowish brown & Grayish brown \\
Powder $+\mathrm{KMnO}_{4}$ & Dark brown & Reddish brown \\
Powder $+\mathrm{KOH}$ & Pale brown & Grayish green \\
Powder $+\mathrm{Alc} . \mathrm{NaOH}$ & Faint yellow & Yellowish brown \\
Powder $+\mathrm{Alc} . \mathrm{KOH}$ & Pale brown & Yellowish green \\
Powder $+\mathrm{Ammonia}$ & Pale yellow & Yellowish green \\
\hline
\end{tabular}

Table 5: HPTLC fingerprinting and spectrum scan of EN6 extract fraction at $254 \mathbf{n m}$

\begin{tabular}{|c|c|c|c|c|c|c|}
\hline Volume applied & Color of band & Peak No. & $R_{f}$ value & Peak height & Peak area & $\begin{array}{l}\text { Spectrum scan } \\
(200-400 \mathrm{~nm})\end{array}$ \\
\hline \multirow[t]{2}{*}{$2 \mu \mathrm{l}$} & Dark green & 1 & 0.10 & 29.0 & 519.9 & -- \\
\hline & & 2 & 0.19 & 13.9 & 290.8 & \\
\hline \multirow[t]{5}{*}{$4 \mu \mathrm{l}$} & Light green & 1 & 0.01 & 13.4 & 136.9 & -- \\
\hline & & 2 & 0.10 & 52.0 & 987.2 & \\
\hline & & 3 & 0.18 & 18.7 & 492.9 & \\
\hline & & 4 & 0.46 & 13.6 & 278.7 & \\
\hline & & 5 & 0.55 & 14.6 & 314.3 & \\
\hline \multirow[t]{6}{*}{$6 \mu \mathrm{l}$} & Yellowish green & 1 & 0.01 & 21.4 & 210.5 & -- \\
\hline & & 2 & 0.10 & 71.6 & 1437.6 & \\
\hline & & 3 & 0.19 & 29.0 & 663.7 & \\
\hline & & 4 & 0.46 & 15.8 & 338.9 & \\
\hline & & 5 & 0.55 & 17.9 & 411.2 & \\
\hline & & 6 & 0.63 & 13.5 & 248.0 & \\
\hline \multirow[t]{7}{*}{$8 \mu \mathrm{l}$} & Yellow & 1 & 0.01 & 30.3 & 309.1 & -- \\
\hline & & 2 & 0.10 & 89.6 & 1774.2 & \\
\hline & & 3 & 0.18 & 34.4 & 817.7 & \\
\hline & & 4 & 0.31 & 10.4 & 154.2 & \\
\hline & & 5 & 0.45 & 22.1 & 387.3 & \\
\hline & & 6 & 0.55 & 22.5 & 520.8 & \\
\hline & & 7 & 0.63 & 15.6 & 270.0 & \\
\hline \multirow[t]{7}{*}{$10 \mu \mathrm{l}$} & Light orange & 1 & 0.01 & 34.6 & 365.9 & 265 \\
\hline & & 2 & 0.09 & 104.0 & 2092.0 & 263 \\
\hline & & 3 & 0.18 & 41.1 & 906.7 & 400 \\
\hline & & 4 & 0.31 & 11.0 & 205.9 & 400 \\
\hline & & 5 & 0.45 & 27.8 & 569.0 & 382 \\
\hline & & 6 & 0.55 & 26.4 & 564.0 & 383 \\
\hline & & 7 & 0.63 & 19.2 & 356.8 & 400 \\
\hline \multirow[t]{9}{*}{$15 \mu \mathrm{l}$} & Orange & 1 & 0.01 & 42.5 & 441.6 & 265 \\
\hline & & 2 & 0.05 & 12.1 & 164.0 & 369 \\
\hline & & 3 & 0.09 & 125.2 & 2663.6 & 264 \\
\hline & & 4 & 0.20 & 55.7 & 1244.3 & 279 \\
\hline & & 5 & 0.31 & 21.6 & 412.9 & 400 \\
\hline & & 6 & 0.44 & 79.2 & 1627.6 & 378 \\
\hline & & 7 & 0.54 & 73.0 & 1615.1 & 377 \\
\hline & & 8 & 0.62 & 28.5 & 512.4 & 400 \\
\hline & & 9 & 0.71 & 11.1 & 278.7 & 397 \\
\hline
\end{tabular}


Table 6: HPTLC fingerprinting of EN6 extract fraction at $366 \mathrm{~nm}$ and $540 \mathrm{~nm}$

\begin{tabular}{|c|c|c|c|c|c|c|c|c|c|c|}
\hline \multirow{2}{*}{$\begin{array}{l}\text { Volume } \\
\text { applied }\end{array}$} & \multirow[t]{2}{*}{ Color of band } & \multicolumn{4}{|c|}{ Scanned at $366 \mathrm{~nm}$} & \multirow[t]{2}{*}{ Color of band } & \multicolumn{4}{|c|}{ Scanned at $540 \mathrm{~nm}$} \\
\hline & & $\begin{array}{l}\text { Peak } \\
\text { No. }\end{array}$ & $R_{f}$ value & $\begin{array}{c}\text { Peak } \\
\text { height }\end{array}$ & $\begin{array}{l}\text { Peak } \\
\text { area }\end{array}$ & & $\begin{array}{l}\text { Peak } \\
\text { No. }\end{array}$ & $R_{f}$ value & $\begin{array}{l}\text { Peak } \\
\text { height }\end{array}$ & $\begin{array}{c}\text { Peak } \\
\text { area }\end{array}$ \\
\hline \multirow[t]{6}{*}{$2 \mu \mathrm{l}$} & Dark green & 1 & 0.34 & 15.2 & 97.1 & Dark green & 1 & 0.09 & 20.8 & 654.7 \\
\hline & & 2 & 0.45 & 105.9 & 1054.7 & & 2 & 0.14 & 22.5 & 310.5 \\
\hline & & & & & & & 3 & 0.38 & 68.5 & 3032.0 \\
\hline & & & & & & & 4 & 0.48 & 88.8 & 2488.3 \\
\hline & & & & & & & 5 & 0.57 & 37.3 & 1133.9 \\
\hline & & & & & & & 6 & 0.64 & 34.9 & 1132.1 \\
\hline \multirow[t]{6}{*}{$4 \mu \mathrm{l}$} & Light green & 1 & 0.45 & 6.9 & 173.1 & Light green & 1 & 0.08 & 36.8 & 1144.9 \\
\hline & & 2 & 0.55 & 6.1 & 106.1 & & 2 & 0.16 & 36.7 & 673.2 \\
\hline & & & & & & & 3 & 0.38 & 70.8 & 3169.1 \\
\hline & & & & & & & 4 & 0.48 & 136.4 & 3262.5 \\
\hline & & & & & & & 5 & 0.57 & 53.7 & 1367.8 \\
\hline & & & & & & & 6 & 0.64 & 57.4 & 1749.9 \\
\hline \multirow[t]{7}{*}{$6 \mu \mathrm{l}$} & Yellowish & 1 & 0.45 & 10.3 & 244.6 & Yellowish & 1 & 0.01 & 12.8 & 120.0 \\
\hline & green & 2 & 0.55 & 8.3 & 179.7 & green & 2 & 0.08 & 52.7 & 1612.5 \\
\hline & & 3 & 0.77 & 6.0 & 40.8 & & 3 & 0.17 & 46.3 & 757.0 \\
\hline & & & & & & & 4 & 0.38 & 72.3 & 3037.2 \\
\hline & & & & & & & 5 & 0.48 & 173.1 & 3953.9 \\
\hline & & & & & & & 6 & 0.57 & 68.4 & 1753.1 \\
\hline & & & & & & & 7 & 0.64 & 75.6 & 2218.6 \\
\hline \multirow[t]{8}{*}{$8 \mu \mathrm{l}$} & Yellow & 1 & 0.05 & 6.8 & 35.0 & Yellow & 1 & 0.01 & 12.3 & 142.9 \\
\hline & & 2 & 0.45 & 14.7 & 362.0 & & 2 & 0.09 & 63.7 & 1951.0 \\
\hline & & 3 & 0.55 & 11.5 & 250.1 & & 3 & 0.18 & 50.6 & 788.0 \\
\hline & & & & & & & 4 & 0.31 & 11.8 & 201.1 \\
\hline & & & & & & & 5 & 0.38 & 77.9 & 3373.7 \\
\hline & & & & & & & 6 & 0.48 & 201.6 & 4692.7 \\
\hline & & & & & & & 7 & 0.57 & 81.7 & 2078.7 \\
\hline & & & & & & & 8 & 0.64 & 91.3 & 2626.0 \\
\hline \multirow[t]{9}{*}{$10 \mu \mathrm{l}$} & Light orange & 1 & 0.32 & 5.9 & 109.7 & Light orange & 1 & 0.01 & 11.1 & 150.3 \\
\hline & & 2 & 0.45 & 19.0 & 479.8 & & 2 & 0.09 & 78.7 & 2312.7 \\
\hline & & 3 & 0.55 & 15.2 & 319.5 & & 3 & 0.18 & 63.2 & 918.2 \\
\hline & & & & & & & 4 & 0.31 & 13.0 & 248.0 \\
\hline & & & & & & & 5 & 0.38 & 84.3 & 3423.8 \\
\hline & & & & & & & 6 & 0.48 & 222.6 & 5108.5 \\
\hline & & & & & & & 7 & 0.57 & 94.7 & 2289.2 \\
\hline & & & & & & & 8 & 0.64 & 104.3 & 3039.7 \\
\hline & & & & & & & 9 & 0.74 & 12.1 & 403.7 \\
\hline \multirow[t]{10}{*}{$15 \mu \mathrm{l}$} & Orange & 1 & 0.05 & 78.8 & 1682.0 & Orange & 1 & 0.08 & 102.9 & 3023.1 \\
\hline & & 2 & 0.12 & 7.9 & 39.1 & & 2 & 0.19 & 58.0 & 985.1 \\
\hline & & 3 & 0.19 & 8.0 & 108.7 & & 3 & 0.24 & 13.6 & 237.5 \\
\hline & & 4 & 0.27 & 7.2 & 36.7 & & 4 & 0.31 & 19.2 & 341.4 \\
\hline & & 5 & 0.33 & 19.9 & 358.7 & & 5 & 0.38 & 97.7 & 4245.0 \\
\hline & & 6 & 0.41 & 12.8 & 155.8 & & 6 & 0.48 & 268.8 & 6342.9 \\
\hline & & 7 & 0.44 & 40.6 & 855.7 & & 7 & 0.57 & 125.4 & 3671.6 \\
\hline & & 8 & 0.54 & 39.1 & 779.4 & & 8 & 0.63 & 131.7 & 3974.1 \\
\hline & & 9 & 0.70 & 21.0 & 561.6 & & 9 & 0.72 & 17.5 & 342.9 \\
\hline & & & & & & & 10 & 0.74 & 18.0 & 303.9 \\
\hline
\end{tabular}


light shows fluorescence in various herbal drugs. As per literature report, alkaloid such as berberine is not visible in day light. It is due to decomposition of drugs due to fluorescent derivatives after treating with various chemical reagents. ${ }^{51}$ Results of quantitative estimation of phytoconstituents indicates that $E$. neriifolia leaves have more percentage of saponin content $(3.67 \%)$ than alkaloid content $(0.26 \%)$. Hence, quantitative and fluorescence standard of powder provides valuable information to substantiate and authenticate the phytomedicine. Primary HPTLC fingerprinting analysis results showed there is a presence of huge number of phytoconstituents with respect to their Rf values and UV-visible spectra's (200-400 nm) scanned at $254 \mathrm{~nm}, 366 \mathrm{~nm}$ and after derivatization at $540 \mathrm{~nm}$. These phytoconstituents may includes, flavonoids, terpenes, steroidal saponins, alkaloids, glycosides, tannins and phenolic acids, etc. with promising biological actions which can be utilized to expand prospective drugs. Based on the results, there is a recommendation to co-relate these phytoconstituents present in the EN6 extract fraction with various standard marker compounds for its identification, confirmation and validation by analytical research. Similarly, for other chemical constituent's isolation technique are required to be developed. Based on reported biological activities E. neriifolia extracts and isolates can be explored for their therapeutic potential by use of modern assay methods. ${ }^{52}$ The present investigation is an additional standardization research in support with previous reports and will be helpful for qualitative and quantitative standardization of herbal formulations containing E. neriifolia as $E$. neriifolia leaves might be utilized as a potential therapeutic agent. Further investigations are going on this extract fraction in reference to identification, quantification and validation of HPTLC methods using various standard marker compounds along with exploration of its pharmacological activities.

\section{ACKNOWLEDGEMENT}

Authors are grateful to Scientist, Botany, Vindhya Herbal Testing and Research Laboratory, MFP-PARC, Barkheda Pathani, Bhopal and Anchrom Test Lab Pvt. Ltd., Mumbai for availing the necessary facilities to perform this research work.

\section{CONFLICT OF INTEREST}

We declare that we have no conflict of interest.

\section{ABBREVIATION USED}

E. neriifolia: Euphorbia neriifolia Linn.; HPTLC: High performance thin layer chromatography; $\mathrm{NaOH}$ : Sodium hydroxide; KMnO4: Potassium permagnet; H2SO4: Suphuric acid; KOH: Pottasium hydroxide.

\section{REFERENCES}

1. Kirtikar KR, Basu BD. Indian Medicinal Plants. $2^{\text {nd }}$ ed., Vol. III. Allahabad: Lalit Mohan Basu; 2006. p. 2201-2204.

2. Webster GL. Classification of the Euphorbiaceae. Ann Mo Bot Gard. 1994; 81: 03-32.

3. Mwine JT, Van Damme P. Why do Euphorbiaceae tick as medicinal plants? A review of Euphorbiaceae family and its medicinal features. Journal of Medicinal Plants Research. 2011;5(5):652-62.

4. Pickard WF. Laticifers and secretory ducts: two other tube systems in plants. New Phytologist. 2008;177(4):877-88.

5. Chunekar KC. Illustrated Dravyaguna Vijnana. $2^{\text {nd }}$ ed., Vol. II. Varanasi: Chaukhambha Orientalia; 2005. p. 924-925.

6. The Ayurvedic Pharmacopoeia of India. Part-I, Vol. I, $1^{\text {st }}$ Ed., Controller of Publications, Ministry of Health and Family Welfare, Department of Indian Systems of Medicine and Homoeopathy, Government of India. New Delhi: National Institute of Science Communication (CSIR); 2001.

7. Ng AS. Diterpenes from Euphorbia neriifolia. Phytochemistry. 1990;29(2):662-4.

8. Gaur K, Rana AC, Nema RK, Kori ML, Sharma CS. Anti-inflammatory and analgesic activity of hydro-alcoholic leaves extract of Euphorbia neriifolia Linn. Asian journal of pharmaceutical and clinical research. 2009;2(1):26-9.
9. Bigoniya P, Rana AC. Pharmacological screening of Euphorbia neriifolia leaf hydroalcoholic extract. Journal of Applied Pharmaceutical Science. 2010;1 (2):1-7.

10. Bigoniya P, Rana AC. Psychopharmacological profile of hydro-alcoholic extract of Euphorbia neriifolia leaves in mice and rats.

11. Ilyas M, Parveen M, Hasan MHM, Omer AB. A novel triterpene (Neriifolione): A potent anti-inflammatory and antiarthritic agent from Euphorbia neriifolia. Hamdard Medicus. 2003;(2):97-102.

12. Bigoniya P, Rana AC. Protective effect of Euphorbia neriifolia saponin fraction on CCl4-induced acute hepatotoxicity. Afri J Biotech. 2010; 9(42):7148-56.

13. Sharma V, Janmeda P, Paliwal R, Singh L, Sharma V, Sharma S. Anticarcinogenic potential of $E$. neriifolia leaves against $n$-nitrosodiethylamine-induced nephrotoxicity in mice. Biochem Cell Arch. 2011;11(2):393-8.

14. Sharma $V$, Janmeda P. Chemopreventive role of Euphorbia neriifolia (Linn) and its isolated flavonoid against n-nitrosodiethylamine-induced renal histopathological damage in male mice. Toxicol Int. 2013;20:101-7.

15. Janmeda P, Sharma V, Singh L, Paliwal R, Sharma S, et al. Chemopreventive effect of hydroethanolic extract of Euphorbia neriifolia leaves against DENAinduced renal carcinogenesis in mice. Asian Pac J Cancer Prev. 2011;12(3):677-83.

16. Mansuri MI, Patel VM. Anti-diabetic Potential of Euphorbia neriifolia Linn. Alloxan Induced Diabetic Rats. Journal of Pharmacy Research. 2012;5(5):2571-3.

17. Bigoniya P, Shukla A, Singh CS. Dermal irritation and sensitization study of Euphorbia neriifolia latex and its anti-inflammatory efficacy. Int J Phytomed. 2010; 2: 240-254

18. Hasan M, Ganeshpurkar A, Bansal D, Dubey N. Protective effect of Euphorbia neriifolia extract on experimentally induced thrombosis in murine model. Nigerian Journal of Experimental and Clinical Biosciences. 2014;2(2):86-9

19. Pracheta J, Sharma V, Paliwal R, Sharma SP. In-vitro free radical scavenging and antioxidant potential of ethanolic extract of Euphorbia neriifolia Linn. Int J Pharm Pharmacet Sci. 2011;3(1):238-42

20. Bigoniya P, Rana AC. Subacute effect of Euphorbia neriifolia Linn. on hematological, biochemical and antioxidant enzyme parameters of rat. Academic Journal of Plant Sciences. 2009;2(4):252-9.

21. Babar RS, Kataware UP, Mali NN, Patil SB, Naikwade NS. In-vitro cytotoxicity activity of Euphorbia hirta, Euphorbia tirucalli and Euphorbia neriifolia extract against B16F10 melanoma cell line. Inventi Impact: Ethnopharmacology. 2012;3(3). http://inventi.in/journal/article/impact/3/3174/ethnopharmacology/pi [Last assessed on 2016 Dec 12].

22. Patil SB, Magdum CS. Determination of $L_{50}$ values of extracts of Euphorbia hirta Linn and Euphorbia neriifolia Linn. Using brine shrimp lethality assay. Asian J Res Pharm Sci. 2011;1(2):42-3.

23. Kazufumi T, Takafumi N, Tahmina H, Takashi O, Midori AA, Takashi K, Thaworn K Masami I. Cycloartane triterpenes and ingol diterpenes isolated from Euphorbia neriifolia in a screening program for death-receptor expression-enhancing activity. Planta Med. 2012;78:1370-1377.

24. Bigoniya P, Rana AC. Immunomodulatory activity of Euphorbia neriifolia leaf hydro-alcoholic extract in rats. Indian Drugs. 2008;45(2):90-7.

25. Gaur K, Rana AC, Chauhan LS, Sharma CS, Nema RK, Kori ML. Investigation of immunomodulatory potential of Euphorbia neriifolia Linn. Against betamethasone induced immunosuppression. Int. J. Pharm. Phytochem. Res. 2009;1:8-11.

26. Yadav RP, Patel AK, Jagannadham MV. Neriifolin S, a dimeric serine protease from Euphorbia neriifolia Linn.: Purification and biochemical characterisation. Food chemistry. 2012;132(3):1296-304.

27. Yadav RP, Patel AK, Jagannadham MV. Purification and biochemical characterization of a chymotrypsin-like serine protease from Euphorbia neriifolia Linn. Process Chem. 2011;46:1654-62.

28. Mallavadhani UV, Satyanarayana KV, Mahapatra A, Sudhakar AV. A new tetracyclic triterpene from the latex of Euphorbia nerifolia. Natural product research. 2004 18(1):33-7.

29. Mallavadhani UV, Satyanarayana KVS, Mahapatra A, Sudhakar AVS, Narasimhan K, et al. Development of Diagnostic Microscopic and Chemical Markers of Some Euphorbia Latexes. J Integrative Plant Biology. 2006;48(9):1115-21.

30. Ilyas M, Parveen M, Amin KM. Neriifolione, a triterpene from Euphorbia neriifolia. Phytochemistry. 1998;48(3):561-3.

31. Roa DN, Row LR. The crystalline principles of Euphorbiaceae. Part III. Curr Sci. 1965;34(14):432.

32. Seshagirirao K, Prasad MN. Purification and partial characterization of a lectin from Euphorbia neriifolia latex. Biochemistry and molecular biology international. 1995;35(6):1199-204.

33. Toume K, Nakazawa T, Hoque T, Ohtsuki T, Arai MA, et al. Cycloartane triterpenes and ingol diterpenes isolated from Euphorbia neriifolia in a screening program for death-receptor expression-enhancing activity. Planta medica. 2012;78(12):1370-7.

34. Anjaneyulu V, Row LR. The crystalline principles of Euphorbiaceae. Part IV. Curr Sci. 1965;21:608-9.

35. Sharma $V$, Janmeda P. Extraction, isolation and identification of flavonoid from Euphorbia neriifolia leaves. Arabian Journal of Chemistry. 2014. dx.doi. org/10.1016/j.arabjc.2014.08.019. [Last assessed on 2017 April 11].

36. Sharma V, Janmeda P. Chromatography fingerprinting profile studies on the 
flavonoids of Euphorbia neriifolia (Linn.) leaves. Int J Drug Dev Res. 2013,5(1):286-96.

37. Suresh Kumar SV, Mishra SH. Hepatoprotective effect of extracts from Pergularia daemia Forsk. J Ethanopharmacol. 2006; 107:164-8.

38. Mukherjee PK, Rai S, Kumar V, Mukherjee K, Hylands PJ, et al. Plants of Indian origin in drug discovery. Expert Opin Drug Discov. 2007;2(5):633-57.

39. World Health Organization. Research guidelines for evaluating the safety and efficacy of herbal medicines. Geneva: World Health Organization; 1993. Available from: http://apps.who.int/medicinedocs/en/d/Jh2946e/ [Accessed on 25th October, 2013]

40. Makhija IK, Richard L, Kirti SP, Saleemullah K, Jessy M, et al. Sphaeranthus indicus: A review of its chemical, pharmacological and ethnomedicinal properties. International Journal of Pharmacology. 2011;7(2):171-9.

41. Brain KR, Turner TD. The practical evaluation of phytopharmaceuticals. Bristol: Wright-Scientechnica; 1975

42. World Health Organization. Quality control methods for medicinal plant material. Geneva; 1998.

43. Khandelwal KR. Practical Pharmacognosy: Techniques and experiments. $19^{\text {th }}$ ed., Pune: Nirali Prakashan; 2008.

44. Kokate CK. Practical Pharmacognosy. $4^{\text {th }}$ ed., New Delhi: Vallabh Prakashan; 2007.

45. Chase CR, Pratt R. Fluorescence of powdered vegetable drugs with particular reference to development of a system of identification. J Pharm Sci. 1949; 38(6):324-31.

46. Kokoski CJ, Kokoski RJ, Slama FJ. Fluorescence of powdered vegetable drugs under ultraviolet radiation. Journal of the American Pharmaceutical Association. 1958;47(10):715-7.

47. Harbone JB, Phytochemical Methods- A Guide to Modern Techniques of Plant Analysis, $3^{\text {rd }}$ ed., London: Chapman and Hall; 1998.

48. Obadoni BO, Ochuko PO. Phytochemical studies and comparative efficacy of the crude extracts of some haemostatic plants in Edo and Delta States of Nigeria. Global Journal of pure and applied sciences. 2002;8(2):203-8.

49. Orhan I, Küpeli E, Sener B, Yesilada E. Appraisal of anti-inflammatory poten tial of the clubmoss, Lycopodium clavatum L. Journal of ethnopharmacology. 2007;109(1):146-50.

50. Sharma B, Balomajumder C, Roy P. Hypoglycemic and hypolipidemic effects of flavonoid rich extract from Eugenia jambolana seeds on streptozotocin induced diabetic rats. Food and chemical toxicology. 2008 ;46(7):2376-83.

51. Mukherjee PK. Quality control of herbal drugs: an approach to evaluation of botanicals. New Delhi: Business Horizons Publication. 2002.

52. Mali PY, Panchal SS, Euphorbia neriifolia L.: Review on botany, ethnomedicinal uses, phytochemistry and biological activities. Asian Pacific Journal of Tropical Medicine. 2017:10(5): 430-438.

\section{GRAPHICAL ABSTRACT}

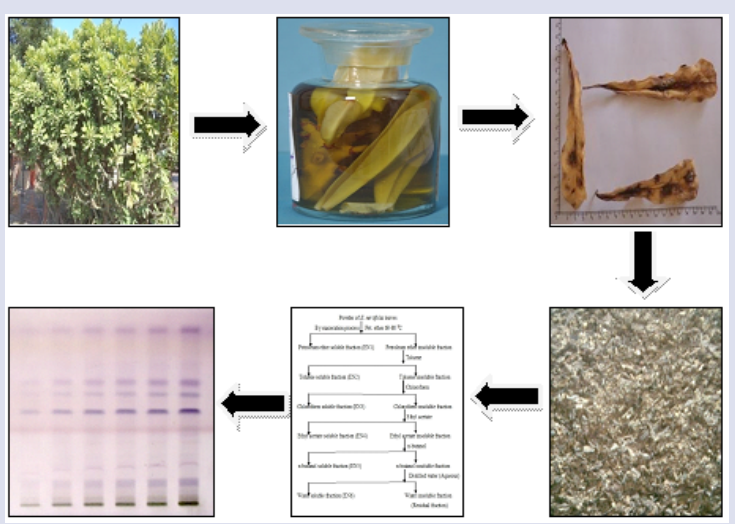

\section{HIGHLIGHTS OF PAPER}

- Pharmacognostical and physico-chemical standardization of $E$. neriifolia leaves

- Extraction and fractionation of E. neriifolia leaves with different solvents

- Primary phytochemical, fluorescence and quantitative screenings of E. neriifolia

- $\quad$ Primary HPTLC fingerprinting assessment of EN6 aqueous extract fraction of E. neriifolia

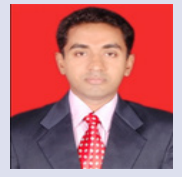

AUTHOR PROFILE

Mr. Prashant Y. Mali: I am pursuing Ph.D. degree from Institute of Pharmacy, Nirma University, Ahmedabad, Gujarat. I have more than 08 years of teaching experience including one academic year at School of Health and Hospital, Adama Science and Technology University, Adama, ETHIOPIA (Africa Cotenant). I have written 02 books for pharmacy professionals entitled "Essential Web Resources in Pharmacy" and "Pharmacology-I" having ISBN Numbers. Under my authorship 33 research and 18 review articles along with 06 chapters in book series were published in the journals and books of National and International repute. I have presented 14 (International) and 15 (National) papers in the conferences of good impact, of which in MALAYSIA and NEPAL Countries. Apart from these, I have participated in 01 (FDP), 09 (training courses), 04 (workshops). I am life member of APTI, InPharm Association and Pharma HelpLine Society.

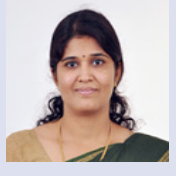

Dr. Shital S. Panchal: I have more than 14 years of teaching and research experience. 55 Research and review articles published in reputed Indian and International journals as well as one reference book entitled "Essential Web Resources in Pharmacy". Presented more than 45 presentations as author or co-author in various state level, national level and international level. Chaired scientific session at International Society of Ethnopharmacology conference. Recognized post-graduate and Ph.D. guide of Nirma University. Research areas of interest are clinical and pre-clinical studies, gastrointestinal disorders including cancer, ocular pharmacology and cardiovascular complications. Life member of professional bodies like ISE, IPA, IPGA and IPS.

Cite this article : Mali PY and Panchal SS. Pharmacognostical and Physico-chemical Standardization of Euphorbia neriifolia Leaves. Pharmacog J. 2017;9(5):696-705. 